\title{
HUBUNGAN DUKUNGAN KELUARGA DENGAN KUALITAS HIDUP ORANG DENGAN GANGGUAN JIWA
}

\author{
Kadek Putra Sanchaya ${ }^{1}$, Ni Made Dian Sulistiowati ${ }^{2}$, Ni Putu Emy Darma Yanti ${ }^{1}$ \\ ${ }^{1}$ Program Studi Ilmu Keperawatan, Fakultas Kedokteran Universitas Udayana \\ ${ }^{2}$ Departemen Keperawatan Jiwa, Program Studi Ilmu Keperawatan, Fakultas Kedokteran, Universitas Udayana \\ Email: sulistiowati.md@unud.ac.id
}

\begin{abstract}
ABSTRAK
Gangguan jiwa merupakan salah satu masalah kesehatan yang cukup serius. Keluargamemilikiwaktu yang lebihbanyakuntukmemberikanperawatankepada ODGJ di rumah.Orang dengan Gangguan Jiwa (ODGJ) biasanya memiliki masalah terhadap kualitas hidup. Penelitian ini bertujuan untuk mengetahui hubungan antara dukungan keluarga dengan kualitas hidup ODGJ. Penelitian ini merupakan penelitian kuantitatif menggunakan rancangan cross-sectional dengan metode analitik korelatif. Sampel penelitian sebanyak 39 orang dipilih dengan teknik non probability sampling jenis purposive sampling. Pengumpulan data karakteristik responden dilakukan menggunakan kuesioner karakteristik responden. Tingkat dukungan keluarga dinilai menggunakan kuesioner dukungan keluarga oleh Friedman dan kualitas hidup responden diukur menggunakan kuesioner SQLS. Hasil penelitian menunjukan bahwa dukungan keluarga baik dan sedang memiliki persentase sama yaitu 35,9\%, sedangkan hasil penilaian kualitas hidup menunjukan mayoritas responden memiliki kualitas hidup baik $(82,1 \%)$. Berdasarkan analisis menggunakan uji Spearman-Rank, terdapat hubungan yang signifikan antara dukungan keluarga dengan kualitas hidup responden dengan nilai $\mathrm{p}=0,000(\mathrm{p}<0,05)$ serta nilai korelasi kuat yaitu 0,618dan arah korelasi positif yang berarti apabiladukungankeluargameningkatmakakualitashidup responden akanmeningkat dan begitu pula sebaliknya. Peneliti selanjutnya diharapkan dapat melakukan kontrol terhadap faktor-faktor lain yang dapat mempengaruhi kualitas hidup ODGJ.
\end{abstract}

Kata kunci: Dukungan keluarga, gangguan jiwa, kualitas hidup

\section{THE RELATIONSHIP BETWEEN FAMILY SUPPORT AND THE QUALITY OF LIFE OF PEOPLE WITH MENTAL DISORDERS}

\begin{abstract}
Mental disorder is one of the most serious health problems. Families have to spend more time to provide care to People with Mental Disorders at home. People with Mental Disorders (ODGJ) usually have problems with quality of life. The study aimed to determine the relationship between family support and the quality of life of People with Mental Disorders / ODGJ. This research is a quantitative research by using cross-sectional design with correlative analytic method. The sample of the research were 39 people selected by non probability sampling technique of purposive sampling. Data collection of respondent characteristics was conducted by using questionnaire of respondent characteristics. The level of family support was assessed by using family support questionnaires proposed by Friedman and the quality of life of the respondents was measured using the SQLS questionnaires. The findings showed that good and moderate family supports have the same percentage of $35.9 \%$, while the results of the quality of life score showed that the majority of respondents had good quality of life (82.1\%). Based on the analysis by using Spearman-Rank test, there is a significant correlation between family support and quality of life of respondents with $p=$ $0,000(p<0,05)$ and strong correlation value of 0.618 and positive correlation direction which means if family support increases then the quality of life of respondents will increase and vice versa. The future researchers are expected to exercise control over other factors that may affect the quality of life of People with Mental Disorders (ODGJ).
\end{abstract}

Keywords: Family support, mental disorder, quality of life 


\section{PENDAHULUAN}

Gangguan jiwa menjadi masalah yang serius dan menjadi perhatian bagi negara-negara maju serta berkembang di seluruh dunia. Prevalensi masalah kesehatan jiwa di Indonesia sebesar $6,55 \%$ yang artinya dari 100 orang terdapat $6-7$ orang mengalami gangguan jiwa (Maslim, 2012). Bali merupakan salah satu provinsi di Indonesia yang memiliki penyebaran gangguan jiwa yang cukup tinggi prevalensinya. Data dari Riset Kesehatan Dasar (RISKESDAS) (2013) menyatakan bahwa gangguan jiwa berat di provinsi Bali berada pada urutan ke-5 teratas dengan nilai $2,3 \%$ dengan rata-rata gangguan jiwa berat di seluruh indonesia saat itu adalah $1,7 \%$. Berdasarkan data di atas dapat disimpulkan bahwa masalah gangguan kesehatan jiwa saat ini khususnya di Bali sudah menjadi masalah yang sangat serius.

Masalah yang ditimbulkan gangguan jiwa tidak akan menyebabkan kematian secara langsung melainkan akan menyebabkan penderitaan secara fisik dan emosional bagi penderitanya, keluarga dan masyarakat. Salah satu masalah yang ditimbulkan gangguan jiwa adalah terganggunya kualitas hidup Orang Dengan Gangguan Jiwa (ODGJ).Weinberger dan Harrison, (2011) menjelaskan bahwa kualitas hidup ODGJ akan menjadi lebih buruk dari orang lain yang tidak mengalami gangguan jiwa, bahkan kualitas hidupnya akan lebih buruk dari pasien yang menderita penyakit fisik.

Beberapa upaya perawatan sudah dikembangkan di setiap daerah melalui Community Mental Health Nursin g(CMHN), yang merupakan pelayanan kesehatan jiwa yang berada di tingkat komunitas atau Puskesmas. Propinsi Bali sendiri, salah satu wilayah kerja Puskesmas di Kota Denpasar yang sudah melaksanakan CMHN, yaitu PuskesmasII Denpasar Timur. Berdasarkan hasil studi pendahuluan mengenai tingkat kemandirian dan jumlah ODGJ yang sudah memiliki pekerjaan, didapatkan data bahwa hanya $40,7 \%$ pasien sudah mampu melakukan perawatan diri, dari101 ODGJ di wilayah kerja Puskesmas II Denpasar Timurhanya 24,1\% yang sudah bekerja. Oleh karena itulah dapat disimpulkan dengan masih tingginya ketergantungan dan ketidakmandirian maka masih banyak ODGJ memiliki kualitas hidup yang rendah.
Keluarga memiliki waktu yang lebih banyak saat klien diberikan perawatan di rumah, sehingga keluarga memiliki tugas untuk memberikan perawatan ketika pasien tidak dapat memenuhi kebutuhannya sendiri (Stuart, 2007). Berdasarkan pemaparan diatas maka penelitian ini ingin meneliti hubungan dukungan keluarga dengan kualitas hidup orang dengan gangguan jiwa di wilayah kerja Puskesmas II Denpasar Timur.

\section{METODE}

Penelitian ini menggunakan metode kuantitatif yaitu deskriptif korelatif dengan desain crosssectional untuk mengetahui sejauh mana hubungan dukungan keluarga dengan kualitas hidup ODGJ. Penelitian ini menggunakan populasi seluruh ODGJ di wilayah kerja Puskesmas II Denpasar Timur yang terdata sampai 19 November 2016 dengan jumlah 101 orang. Penentuan sampel menggunakan nonprobability sampling dengan purposive sampling sesuai kriteria yang diinginkan. Jumlah sampel yang didapatkan adalah 39 orang. Instrumen penelitian menggunakan kuesioner dukungan keluarga dan kuesioner SQLS. Pengambilan data diawali dengan mengajukan ijin penelitian, selanjutnya setelah didapatkan responden yang diinginkan dilanjutkan dengan menjelaskan penelitian yang dilakukan. Setelah repsonden mengerti dan setuju maka diberikan lembar informed consent sebagai persetujuan mengikuti proses penelitian. Adapun penelitian ini telah lolos uji etik dari Komisi Etik Penelitian Fakultas Kedokteran Universitas Udayana/ RSUP Sanglah Denpasar dengan no 992/14.2/KEP/2017. Analisis yang dilakukan untuk mengetahui ada hubungan variabel indenpenden dengan variabel dependen dengan menggunakan uji rank spearman dengan tingkat kepercayaan $95 \%$.

\section{HASIL}

Berdasarkan tabel 1 didapatkan didapatkan bahwa pada penelitian ini, responden sebagian besar berjenis kelamin laki-laki yaitu sebanyak 28 orang $(71,8 \%)$. Kategori usia responden ppenelitian ini didapatkan bahwa sebagian besar responden berusia 29-36 tahun sebanyak 13 orang $(33,3 \%)$. Dilihat dari status perkawinan responden yang diteliti mayoritas belum menikah dengan jumlah 20 orang $(51,3 \%)$. Sedangkan jika dilihat dari status pekerjaan didapatkan hasil bahwa responden 
yang diteliti sebagian besar tidak bekerja yaitu 27 orang $(69,2 \%)$.

Tabel 1.

Karakteristik responden $(\mathrm{n}=39)$

\begin{tabular}{lll}
\hline Karakteristik & $\mathrm{f}$ & $\%$ \\
\hline Jenis Kelamin & 28 & 71,8 \\
$\quad$ Laki-laki & 11 & 28,2 \\
$\quad$ Perempuan & & \\
Usia & 6 & 15,4 \\
$21-28$ & 13 & 33,3 \\
$29-36$ & 4 & 10,3 \\
$37-44$ & 6 & 15,4 \\
$45-52$ & 9 & 23,1 \\
$53-60$ & 1 & 2,6 \\
61-68 & & \\
Status perkawinan & 20 & 51,3 \\
Belum Menikah & 8 & 20,5 \\
Menikah & 11 & 28,2 \\
$\quad$ Janda/Duda/Berpisah & 12 & 30,8 \\
Status Pekerjaan & 27 & 69,2 \\
$\quad$ Bekerja & hidup baik lebih banyak dari pada yang \\
Tidak Bekerja & memiliki kualitas hidup buruk yaitu sebanyak \\
Pada tabel 2 didapatkan dukungan keluarga \\
baik dan dukungan keluarga sedang memiliki \\
proporsi yang sama besar yaitu 14 orang & 32 orang (82,1\%).
\end{tabular}

(35,9\%).Gambaran kualitas hidup didapatkan

hasil bahwa ODGJ yang memiliki kualitas

Tabel 2.

Gambaran dukungan keluarga dan kualitas hidup ODGJ (n=39)

\begin{tabular}{lcc}
\hline Variabel & f & $\%$ \\
\hline Dukungan Keluarga & & \\
Dukungan Keluarga Baik & 14 & 35.9 \\
Dukungan Keluarga Sedang & 14 & 35.9 \\
Dukungan Keluarga Buruk & 11 & 28.2 \\
\hline Kualitas Hidup & & \\
Kualitas Hidup Baik & 32 & 82.1 \\
Kualitas Hidup Buruk & 7 & 17.9 \\
\hline
\end{tabular}

Tabel 3.

Hubungan dukungan keluarga dengan kualitas hidup ODGJ $(n=39)$

\begin{tabular}{lll}
\hline & \multicolumn{2}{c}{ Kualitas Hidup ODGJ } \\
\cline { 2 - 4 } Dukungan Keluarga & Sig. & 0,618 \\
\hline Berdasarkanujikorelasirank spearman pada & apabila dukungan keluarga mengalami \\
table3 menunjukan hasilnilai p=0,000 yang & penurunan maka kualitas hidup ODGJ akan \\
berarti p $₫, 05$, maka Ha dalam penelitian ini & mengalami penurunan. \\
diterima. Data juga menunjukan bahwa &
\end{tabular}

diterima. Data juga menunjukan bahwa

koefisien korelasi yang didapatkan adalah positif dan kekuatan korelasi yang ditemukan adalah kuat $(\mathrm{r}=0,618)$. Hal ini berarti apabila dukungan keluarga meningkat maka kualitas hidup ODGJ akan meningkat begitu sebaliknya

\section{PEMBAHASAN}

Hasil penelitian menunjukan bahwa berdasarkan jenis kelamin, jenis kelamin lakilaki memiliki proporsi tertinggi dalam sampel penelitian.Laki-laki cenderung memiliki risiko 
yang tinggi untuk mengalami gangguan jiwa dibandingkan dengan perempuan. Kondisi ini dikarenakan adanya penerimaan diri yang lebih baik dari wanita dibandingkan dengan laki-laki (Siegrist, Millier, \& Amri, 2015).

Berdasarkan usia, hasil penelitian ini menunjukan bahwa mayoritas responden memiliki rentang usia 29-36 tahun. Anggraini (2015), melalui penelitiannya juga menyatakan sebagian besar responden yang mengalami gangguan jiwa berusia sekitar 35 tahun. Usia dikaitkan dengan adanya pengalaman seseorang dalam menghadapi berbagai stressor. Kondisi ini kemudian meningkatkan mekanisme koping seseorang dengan melakukan pemanfaatan sumber dukungan yang tersedia.

Hasil penelitian menunjukan bahwa mayoritas responden belum menikah jika dilihat dari status perkawinan. Seseorang yang belum menikah cenderung lebih berisiko dalam mengalami gangguan jiwa.Hasil penelitian ini serupa dengan penelitian Prasetyo (2016), yang menjelaskan di dalam penelitiannya bahwa sebagian besar skizofrenia termasuk dalam kategori belum menikah.

Penelitian ini juga mendapatkan bahwa mayoritas responden adalah responden yang tidak bekerja. Hasil penelitian ini serupa dengan penelitian yang dilakukan oleh Anggraini (2015), dimana pada penelitiannya ditemukan bahwa sebagian besar gangguan jiwa tidak memiliki pekerjaan. Erlina, Soewadi, dan Pranomo (2010), menjelaskan bahwa orang yang tidak bekerja kemungkinan mempunyai risiko 6,2 kali lebih besar menderita gangguan jiwa dibandingkan yang bekerja.

Berdasarkan analisis data yang diperoleh melalui kuesioner dukungan keluarga yang dari 39 responden didapatkan hasil bahwa sebagian besar keluarga memiliki dukungan keluarga baik dan dukungan keluarga sedang yang sama besar. Hasil penelitian menunjukan dukungan keluarga baik dan dukungan keluarga sedang memiliki proporsi yang lebih banyak dibandingkan dengan dukungan keluarga buruk.

Hasil penelitian ini menunjukan ODGJ lebih banyak memiliki kualitas hidup yang baik dibandingkan dengan kualitas hidup yang rendah. Hal ini menunjukan ODGJ yang berada di wilayah kerja Puskesmas II Denpasar Timur sudah sebagian besar memiliki kualitas hidup yang baik.

Penelitian ini ditemukan adanya hubungan yang signifikan antara dukungan keluarga dengan kualitas hidup ODGJ $(\mathrm{p}=0,000)$. Data juga menunjukan bahwa koefisien korelasi yang didapatkan adalah positif dan kekuatan korelasi yang ditemukan adalah kuat yang artinya jika dukungan keluarga meningkat maka kualitas hidup ODGJ juga akan meningkat. Begitu juga sebaliknya, jika dukungan keluarga menurun kualitas hidup ODGJ akan menurun.

Kualitas hidup yang tinggi diikuti oleh peran keluarga yang besar atau dukungan keluarga yang baik. Hal ini tidak lepas dari fungsi perawatan atau pemeliharaan kesehatan oleh keluarga. Dalam fungsi ini, keluarga juga berperan dalam konsep sehat dan sakit ketika anggota keluarga mengalami masalah pada kesehatan sehingga kebutuhan kesehatan anggota keluarganya dapat terpenuhi. Hal ini sejalan dengan penelitian yang dilakukan Sutikno (2011), dimanapadapenelitiannya didapatkan hasil bahwa jika dukungan keluarga tinggi maka kualitas hidup dari lansia bisa 25 kali lebih baik dari kualitas hidup lansia yang memiliki dukungan keluarga rendah.

Dukungan keluarga juga dipengaruhi oleh faktor ekonomi. Dengan ekonomi yang rendah maka fungsi keluarga tidak dapat berjalan dengan baik. Hal ini sejalan dengan penelitian Sutikno (2011), dimana pada penelitiannya dia menjelaskan bahwa fungsi keluarga juga dipengaruhi oleh ekonomi keluarga tersebut. Jika keluarga memiliki ekonomi yang rendah maka keluarga tidak akan dapat mengatasi masalah yang timbul karena masalah kesehatan dan tidak bisa memenuhi kebutuhan kesehatan keluarganya.

Selain memiliki hubungan dengan kualitas hidup, dukungan keluarga juga memiliki hubungan terhadap status gizi. Hal ini didukung oleh penelitian Burhan (2013) dimana pada penelitiannya dijelaskan bahwa perawatan yang dilakukan dengan baik oleh seorang caregiver dapat meningkatkan status 
gizi dan kualitas hidup lansia. Perawatan yang dilakukan oleh seseorang care giver kepada penderita gangguan jiwa tidak hanya memberikan dampak pada ODGJ saja tetapi memiliki dampak yang menguntungkan bagi caregiver sendiri.

Dukungan keluarga juga dapat menurunkan tingkat depresi. Ketika berada di lingkungan masyarakat, ODGJ sering mendapatkan stigma yang negatif dari orang lain. Dengan adanya stigma terhadap ODGJ sering menimbulkan depresi terhadap dirinya. Dengan adanya dukungan keluarga maka depresi yang mungkin terjadi dapat dihindari. Hal ini didukung oleh penelitian yang dilakukan oleh Pratiwi (2014), dimana hasil penelitiannya adalah terdapat hubungan yang signifikan antara dukungan keluarga dengan tingkat depresi dan memiliki korelasi yang negatif. Dari pengamatan yang ditemukan oleh peneliti saat pengambilan data, ODGJ yang mendapatkan dukungan keluarga yang baik sama sekali tidak menunjukan tanda-tanda depresi seperti murung, tidak bersemangat, dan yang lainnya.

\section{SIMPULAN DAN SARAN \\ Simpulan}

Hasil menunjukan terdapat hubungan yang kuat antara dukungan keluarga dengan kualitas hidup ODGJ. Berdasarkan uji statistic sprearman rank didapatkan hasil nilai $\mathrm{p}=000$ $(\mathrm{p}<0,05)$ yang berarti terdapat hubungan antara dukungan keluarga dengan kualitas hidup ODGJ di wilayah kerja Puskesmas II Denpasar Timur dengan arah hubungan yang positif.

\section{Saran}

Hasil penelitian ini diharapkan dapat menjadi masukan bagi keluarga ODGJ untuk dapat digunakan pada keluarga dan masyarakat sebagai acuan dalam perawatan orang dengan gangguan jiwa di rumah.Hasil penelitian inijuga diharapkan dapat menjadi pedoman bagi tenaga kesehatan melihat terdapat hubungan antara dukungan keluarga dengan kualitas hidup sehingga sosialisasi kepada keluarga lebih sering dilakukan untuk menekankan pentingnya dukungan keluarga.

\section{DAFTAR PUSTAKA}

Anggraini, D. (2015). Hubungan antara kemandirian dengan kualitas hidup klien skizofrenia di klinik keperawatan RSJ
Grhasia DIY. (Skripsi Tidak Dipublikasikan). Sekolah Tinggillmu Kesehatan Aisyiyah Yogyakarta (online) (http://opac.unisayogya.ac.id/24/1/Dini\% 20Anggraini_201110201085.pdf, diakses: 18 September 2016)

Burhan, N.I., Taslim, N.A., \&Bahar, B. (2013). Hubungan care giver terhadap status gizi dan kualitas hidup lansia pada etnis bugis. JST Kesehatan, 3(3), 264-273

Erlina, Soewadi, \& Pranomo (2010). Determinan terhadap timbulnya skizofrenia pada pasien rawat jalan di Rumah Sakit Jiwa Prof. Hb Saanin Padang Sumatera Barat.Berita Kedokteran Masyarakat, 26(2), 71-80 (online)

(https://jurnal.ugm.ac.id/bkm/article/vie w/3471/2998, diakses: 30 Mei 2017).

Maslim, R. (2012). Prevalensi dan distribusi masalah kesehatan jiwa di Indonesia. Yogyakarta: UGM

Prasetyo, D.B., \&Puspitosari W. A. (2016). Relationship Between Demographic Factors Quality Of Life Of Patients With Schizophrenia. (Skripsi tidak dipublikasikan).Universitas Muhammadiyah, Yogyakarta (online) (http://repository.umy.ac.id/handle/1234 56789/5875, diakses: 27 Mei 2017)

Pratiwi, D.A. (2014). Hubungan dukungan keluarga dengan tingkat depresi pasien gagal ginjal kronik dengan hemodialisa di RS PKU Muhamadyah Yogyakarta. (Skripsi tidak dipublikasikan).Universitas Muhammadiyah, Yogyakarta (online) (http://opac.unisayogya.ac.id/278/1/publi kasi.pdf, diakses: 29 Mei 2017)

Riset Kesehatan Dasar (Riskesdas). (2013). Pedoman pewawancara petugas pengumpul data. Jakarta: Badan Litbangkes Depkes RI.

Siegrist, K., Millier, A. \& Amri, I. (2015). Association between social contact frequency and negative symptoms, psychosocial functioning and quality of 
life in patients with schizophrenia. Psychiatry Research, 860-866

Stuart, G. W. (2007). Buku saku keperawatan jiwa.(Edisi 5). Jakarta. EGC.

Sutikno, E. (2011).Hubungan fungsi keluarga dengan kualitas hidup lansia. (Tesis tidak dipublikasikan).Universitas

Sebelas Maret, Surakarta (online) (http://eprints.uns.ac.id/8489/1/1931810 11201112361.pdf, diakses: 29 Mei 2017)

Weinberger, D.R.\& Harrison, P.J. (2011). Schizophrenia $\left(3^{\text {rd }}\right.$ edition). USA: Wiley-Blackwell 